11 - ORIGINALARTICLE Experimental Urology

\title{
Effect of finasteride on serum prostate-specific antigen (PSA) and on prostate of hamster Mesocricetus auratus $(\mathrm{h} M a)^{1}$
}

\author{
Efeito da finasterida no antígeno prostático específico (PSA) sérico e na próstata do hamster \\ Mesocricetus auratus (hMa)
}

\author{
Dimas José Araújo Vidigal ${ }^{\mathrm{I}}$, Alcino Lázaro da Silva ${ }^{\mathrm{II}}$, Anilton César Vasconcelos ${ }^{\mathrm{III}}$, Dilermando Resende Fazito ${ }^{\mathrm{IV}}$, Bárbara Lanice \\ Araújo Verçosav $^{\mathrm{V}}$, Nathália Gonsalves Santana ${ }^{\mathrm{VI}}$, Felipe Eduardo Costa Vidigal ${ }^{\mathrm{VII}}$

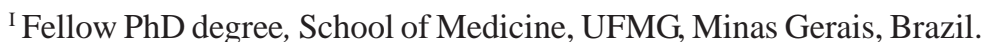 \\ ${ }^{\text {II }}$ Emeritus Professor, School of Medicine, UFMG, Minas Gerais, Brazil.

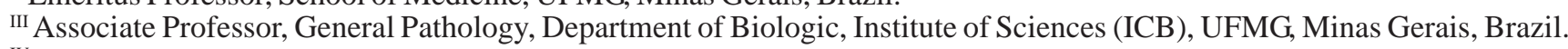 \\ ${ }^{\text {IV }}$ Full Professor, Scientific Methodology, FAME- FUNJOB, Minas Gerais, Brazil. \\ ${ }^{v}$ Fellow Master degree, Veterinary School, ICB-UFMG, Minas Gerais, Brazil. \\ ${ }^{\mathrm{VI}}$ Graduate Student, Veterinary School, ICB-UFMG, Minas Gerais, Brazil.

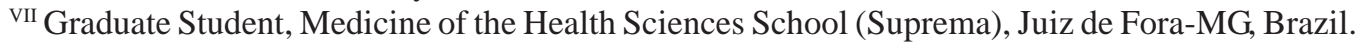

\begin{abstract}
Purpose: Evaluate the effects of finasteride on the serum PSA and on the prostate of hamster-Mesocricetus auratus(hMa). Methods: Twenty $\mathrm{h} M a$ male adults were split in groups control and experimental $(\mathrm{n}=10)$. Animals of the experimental group received 7.14ng/mL of finasteride, subcutaneously (SC) on the back three times per week, during 90 days. The finasteride dose was equivalent to 5.0mg administered to a $70 \mathrm{~kg}$ man. At the end of the experiment the mean age for the animals in the control group was $15.2 \pm 1.13 \mathrm{months}$ and for the experimental group was $17.7 \pm 0.67$ months. There was a statistically significant difference between mean ages of both groups $(t$ value $=5.98 ; p=0.001)$. The animals of the control group weighted $129.0 \pm 18.8 \mathrm{~g}$ and the experimental group weighted $145.0 \pm 15.5 \mathrm{~g}, t=1.88 \mathrm{e}$ $p=0.0514$. The serum PSA was assessed through ELISA method. Prostates of those animals were collected and processed to histology and morphometry: the diameter of the acinous glands and the acinous epithelium, apoptosis, AgNORs and cellularity were assessed in both groups. Results: Serum PSA decreased in the experimental group, $0.003 \mathrm{ng} / \mathrm{mL}$ versus $0.763 \mathrm{ng} / \mathrm{mL}, \mathrm{H}=7.982 \mathrm{e} \mathrm{p}=0.0047$. Decrease in the acinous area occurred in animals that received finasteride, $238.000 \pm 24.600 \mu \mathrm{m}^{2}$ versus $398.600 \pm 55.320 \mu \mathrm{m}^{2} ; \mathrm{t}=2.653 ; \mathrm{p}=0.0122$. A remarkable decrease in the area of the acinous epithelium occurred in the animals that received finasteride, $111.900 \pm 12.820 \mu \mathrm{m}^{2}$ versus $160.400 \pm 18.430 \mu \mathrm{m}^{2} \mathrm{t}=2.162 ; \mathrm{p}=0.0361$. AgNORs were less expressed in finasteride treated animals, $2.846 \pm 0.877$ versus $3.68 \pm 1.07$ argyrophilic clusters for $\mu \mathrm{m}^{2}, \mathrm{p}=<0.0001$. Apoptosis was more intense in the experimental group, $53.62 \pm 1.389$ than in controls, $14.76 \pm$ $2.137, \mathrm{p}=0.0408$. However, there was no statistical difference in the cellularity between both groups, $74.75 \pm 5.5$ cells, in controls versus $65.07 \pm 13.24$, in treated animals, $p=0.5105$. Conclusions: Use of finasteride decreased serum PSA and several histological parameters of the Hamster's prostate, such as lumen area, acinous and epithelium area, and AgNORs expression. Finasteride increased apoptosis in the prostate acinous cells although no significant difference in the cellularity could be found between the two groups of animals under study.
\end{abstract}

Key words: Finasteride. Prostate. Prostate-Specific Antigen. Apoptosis. Mesocricetus.

\section{RESUMO}

Objetivo: Avaliar o efeito da finasterida no PSA sérico e na próstata do hamster-Mesocricetus auratus (hMa). Métodos: 20 hMa adultos machos foram divididos em grupos de 10 animais. No experimento foram administrados 7,14 ng/mL de finasterida, subcutâneo (SC), no dorso, três vezes por semana, por 90 dias, dose equivalente a 5,0 mg usada em homem de $70 \mathrm{Kg}$. Ao final da pesquisa, grupo experimento apresentou idade média de 17,7 $\pm 0,67$ meses. O grupo controle apresentou idade média de 15,2 $\pm 1,13$ meses. O valor de t na comparação das médias das idades entre os dois grupos foi de 5,98 e p=0.0001. Os animais-controle pesaram em média 129,0 $\pm 18,8 \mathrm{~g}$ e o experimento

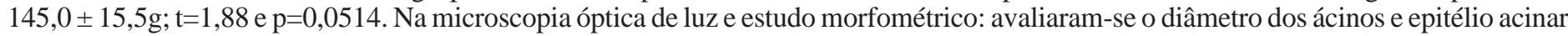
prostáticos, a apoptose, a expressão AgNORs e a celularidade. Resultados: O grupo-experimento apresentou média de PSA de 0,003 ng/ $\mathrm{mL}$ e o grupo-controle de $0,763 \mathrm{ng} / \mathrm{mL}, \mathrm{H}=7,982 \mathrm{e} \mathrm{p}=0,0047$. A área dos ácinos do grupo-experimento foi de $238,000 \pm 24,600 \mu \mathrm{m}^{2}$ versus $398,600 \pm 55,320 \mu \mathrm{m}^{2} ; \mathrm{t}=2,653 ; \mathrm{p}=0,0122$. Aárea do epitélio acinar no grupo-experimento foi de $111,900 \pm 12,820 \mu \mathrm{m}^{2}$ versus $160,400 \pm 18,430$ $\mu \mathrm{m}^{2} \mathrm{t}=2,162 ; \mathrm{p}=0,0361$. A expressão de $\mathrm{AgNORs}$ foi menor no grupo-experimento 2,846 $\pm 0,877$ versus $3,68 \pm 1,07$ grumos argilófilos por $\mu \mathrm{m}^{2}$, $\mathrm{p}=<0,0001$. A apoptose foi mais freqüente no grupo-experimento, 53,62 $\pm 1,389$ versus controle, $14,76 \pm 2,137, \mathrm{p}=0,0408$. Não houve diferença na celularidade entre os grupos de animais, $74,75 \pm 5,5$ células no grupo-controle versus $65,07 \pm 13,24$, no grupo-experimento, $p=$ 0,5105. Conclusões: A finasterida diminuiu o PSA sérico, a área do lúmen, o epitélio acinar, a expressão de AgNORs e promoveu a apoptose nos ácinos da próstata dos hamsteres experimento e não houve diferença na celularidade acinar entre os animais estudados. Descritores: Finasterida. Próstata. Antígeno Prostático Específico. Apoptose. Mesocricetus.

${ }^{1}$ Research performed at the Post-Graduation Program in Sciences Applied to Surgery and Ophthalmology, School of Medicine, Federal University of Minas Gerais (UFMG), Brazil. 


\section{Introduction}

Benign Prostatic Hyperplasia (BPH) is the most common proliferative change of prostate of men, with a histological evidence of $50 \%$ in men over 50 , and almost $90 \%$ evidence after 80 years $^{1}$.

Despite the advances observed in the clinical treatment of prostate diseases and the development of new pharmacological choices, surgical interventions still are the most efficient modality of treatment ${ }^{2}$.

Finasteride (17-beta-N-mono-substituted-carbamoyl-4-aza5 -alpha-androst-1-en-one), which firstly identified in 1984 by Rasmusson et $a l .{ }^{3}$, is one of the first medication used in treatment of $\mathrm{BPH}$.

The assessment of the drug effectiveness is subjective. It depends on: patients' symptoms (American Urological Association Sympson Index $)^{4}$ and rectal touch and ultrasound examination of prostate, to evaluate the gland volume. The uroflowmetry is also used to evaluate the medication effects on the urinary flow ${ }^{5}$.

Clinical manifestations of $\mathrm{BPH}$ are variable and range over the years from exacerbation to amelioration ${ }^{6}$. It has been shown a global improvement in urinary symptoms in $40 \%$ of the patients with BPH who used finasteride for six months ${ }^{7}$. Some clinical improvement was also observed in patients whom under placebo treatment ${ }^{2}$.

The acquired knowledge has shown that between $38 \%$ and $84 \%$ of the patients with BPH, the symptoms relieved or did not show any change, when they were followed for two or five years ${ }^{6}$. The reason for symptom floating is not yet understood.

Generally, the therapeutic response to the use of finasteride has shown modest results ranging between 25 and 30\%, according to population studies ${ }^{7}$. These findings suggest a reasonable doubt about the effectiveness of this medication on the course of BPH.

The studies of finasteride uses and its effects on prostate are based in double-masked study (double blind fashioned study) and placebo controlled studies with random sampling ${ }^{8}$. Eventhough, there is no registry of studies showing the cellular mechanisms of finasteride.

It will be of great value the research for medication to treat $\mathrm{BPH}$, in order to stop the cascade of sequential ineffective treatment strategies that have its fatal end in surgical proceedings or any other intervention ${ }^{9}$.

The anatomic relations in prostate of $\mathrm{hMa}$ are well understood $^{10}$ (Figures 1-3), turning possible the study of medication that affect this gland.

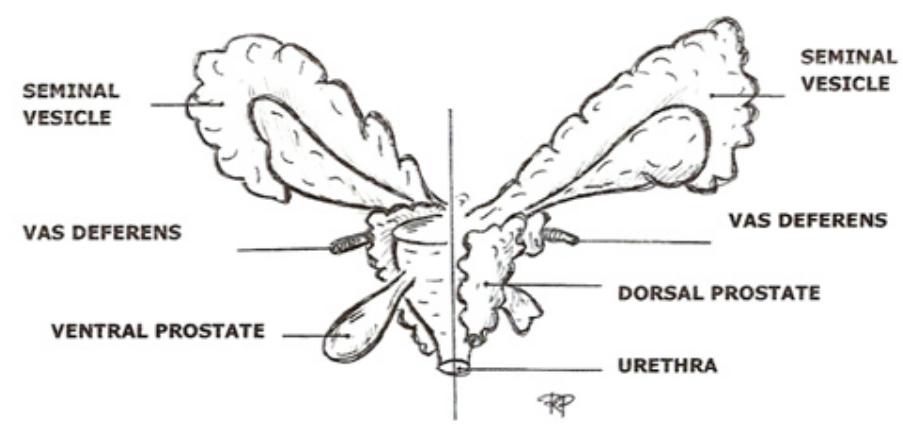

FIGURE 1 - Genital appendage of $\mathrm{h} M a$. Modified from Toma and Buzell $^{10}$

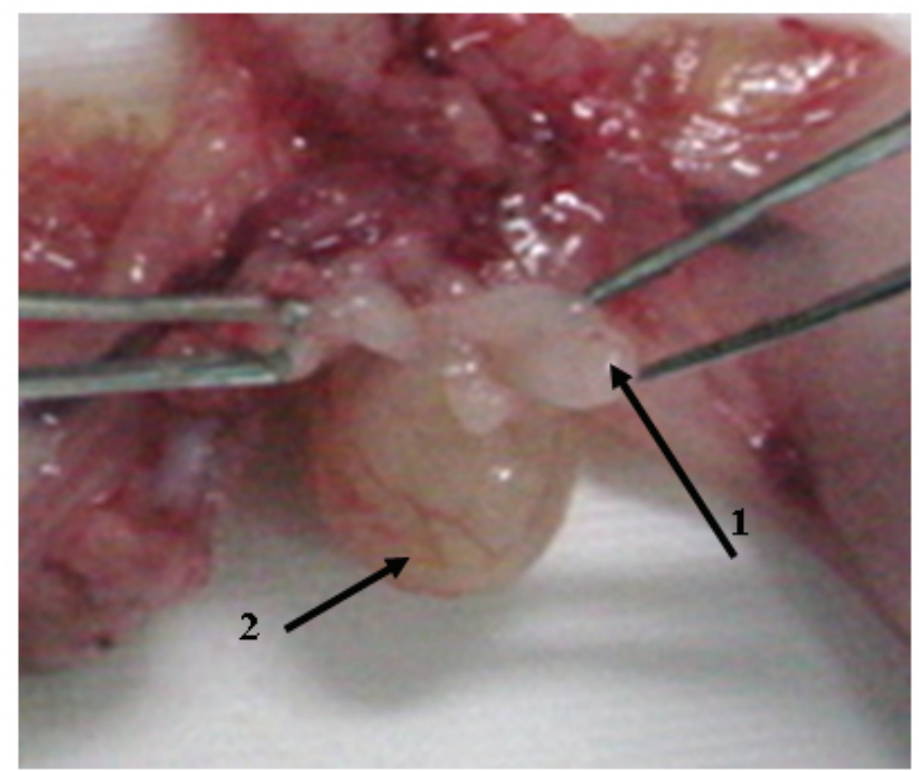

FIGURE 2 - Digital picture of dorsal lobes of prostate from an adult $\mathrm{h} M a$ (arrow 1). Holded by tweezers the prostate lies over the bladder (arrow 2)

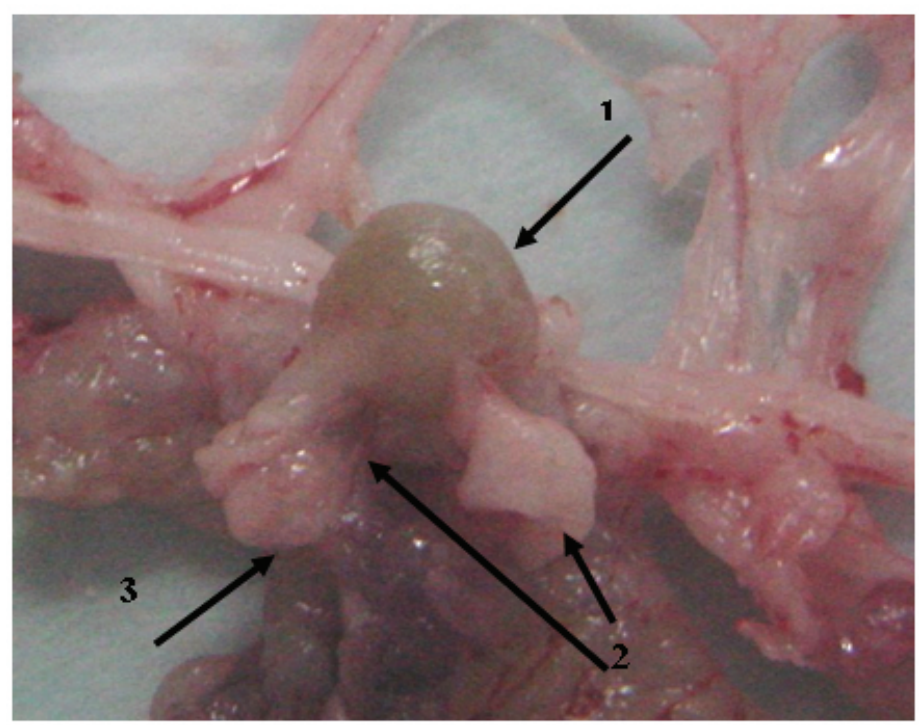

FIGURE 3 - Digital picture of prostate from an adult hMa. The bladder is identified by arrow 1, the ventral lobes by arrow 2 and part of dorsal lobes by arrow 3

Based upon those facts, one should suggest to run that experiment using the $\mathrm{h} M a$ to find evidence of finasteride action on serum PSA, as well as, on prostate of these animals.

\section{Methods}

This research was submitted and approved by the Ethics Committee for Research of the "Presidente Antônio Carlos" University (CEP-UNIPAC), Barbacena, MG, Brazil. Protocol N 129/ 06.

\section{Experimental design}

Twenty adult Mesocricetus auratus (hMa) (N=20) were randomly studied. They were one year or older. The animals were 
assigned to one of two groups: ten $(\mathrm{N}=10)$ in the control group and ten $(\mathrm{N}=10)$ in the experimental group.

The animals were kept in plastic cages of 40x60x20cm wide. Each cage was prepared with shavings and received two hamsters. The food was ad libitum: specific hamster food, sunflower seed, peanut and corn grains. Free water ingestion was also guaranteed by suction water-founders in the cages. The animals were exposed to indirect sunlight for 12 hours daily, and kept under $21^{\circ} \mathrm{C}$ temperature.

Animals in the experimental group received $7.14 \mathrm{ng} / \mathrm{mL}$ of finasteride $(0,5 \mathrm{~mL})$, regardless of the body weight, subcutaneously (SC) on the back (Figure 4), three times per week, during 90 days. This finasteride dose was equivalent to $5.0 \mathrm{mg}$ administered to a $70 \mathrm{~kg}$ man for treatment of BPH.

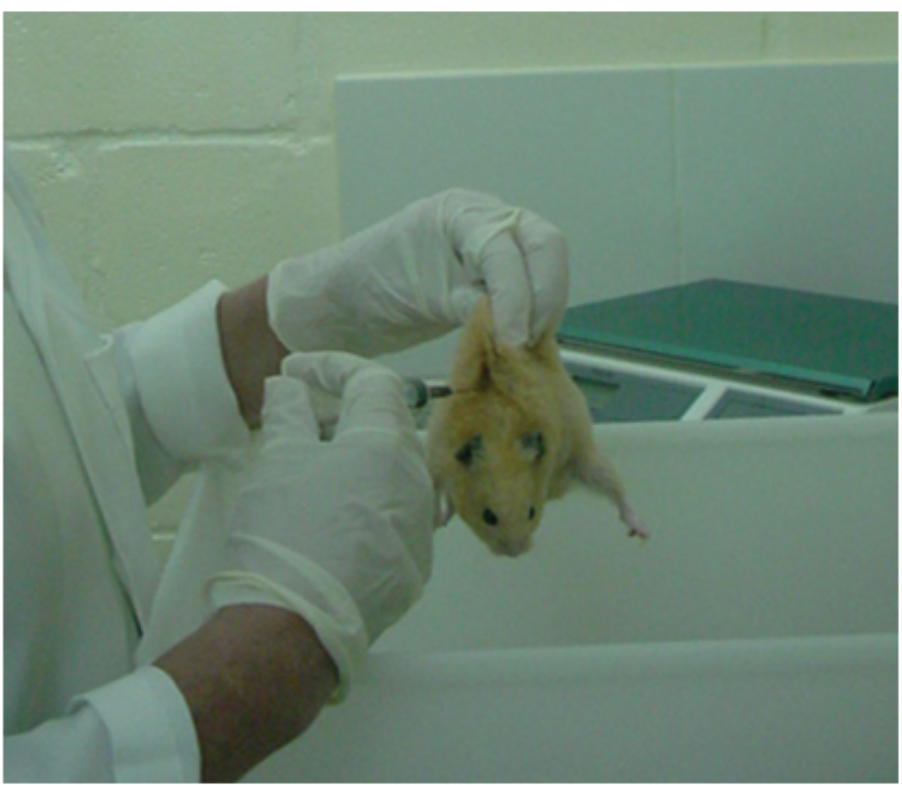

FIGURE 4 - Digital picture showing finasteride administration SC on the back of one of the hMa in the experimental group

After ninety days of medication administration the animals were anesthetized with ketamine chloridrate for veterinary use in a $200 \mathrm{mg} / \mathrm{kg}$ dose and diazepam in a $2.5 \mathrm{mg} / \mathrm{kg}$ dose intraperitoneally ${ }^{11}$, infused through separate syringes. Following anesthesia the animals were sacrificed after induced hypovolemia at the moment of blood samples collection for total PSA dosage ${ }^{11}$. The blood samples were collected in a smooth glass tube without preservative solutions or anticoagulants, following the reagent manufacturer instructions. Serum total PSA was assessed through ELISA method, which has sensibility to $P S A$ of $0.01 \mathrm{ng} / \mathrm{mL}$.

Prostate was removed along with the whole genitourinary apparel via laparotomy ${ }^{11}$. The material was dissected and fixed with $10 \%$ formic aldehyd, followed by histological study.

Ventral and dorsal prostate of the animals were formerly evaluated under the light microscope and then underwent for morphometric analysis at the Apoptosis Laboratory of the Department of General Pathology of the Biologic Institute of Sciences of the Minas Gerais Federal University (ICB-UFMG), Belo Horizonte, MG.

\section{Parameters and morphometric strategy}

Each slide made with the material was assessed for the acinous mean area, as well as, for the mean area of the acinous epithelium, the number of cells (cellularity) in the acinous, the expression of AgNORs (Argyrophilic Nucleolar Organizer Regions) as a marker of activation and cell proliferation and, for the identification in situ of the genome fragmentation as an apoptosis marker through TUNEL reaction (Terminal Deoxinucleotidil Transferase Uracil Nick End Labeling).

The TUNEL technique congregates the immunohistochemical and histochemical principles to mark the fragmented DNA in the apoptotic cells in situ. Histological layers of $4 \mathrm{~mm}$ thickness were made out of paraffin fixed blocs (Figure 5).

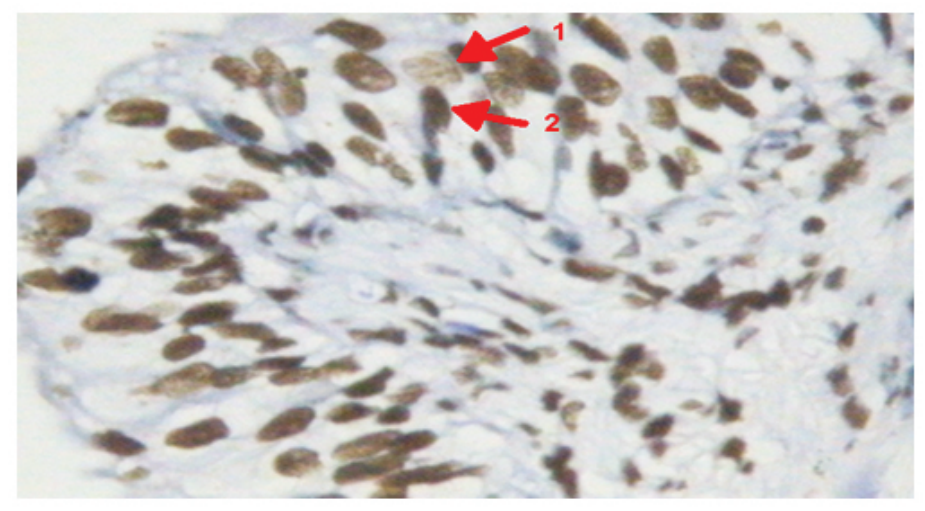

FIGURE 5 - Digital photomicrography of an acinous from prostate of a hMa treated with finasteride (40x objective lenses), using the TUNEL technique. The nucleus identified by arrow 1 is a normal example. The arrow 2 points to a nucleus under apoptosis process

The morphometric evaluation in each microscopic field was referred as a percentage of the counted cells (according to cell type and tainting) for the total number of cells. Moreover, it was quantified on each microscopic field the acinous area and the acinous epithelium area, as well as their mean value.

The counting of the number of acinous cells and acinous epithelium areas in each field was performed through digital images obtained from the histological fields under light microscopy and with a planochromatic $40 \mathrm{X}$ objective lens.

The morphometric parameters considered: mean acinous area, mean acinous epithelium area, number of acinous cells, AgNORs expression and the TUNEL reaction were quantified through digital images captured by microcameras JVC, TK 1270/ JGB and transferred to image analyzers Kontron Elektronics, Carl Zeiss - KS300 version 2.0 and Media Cybernetics Image Pro Plus, version 4.5.0.29. The number of cells in the examined acinous and the nuclei obtained after TUNEL reaction underwent through a manual counting.

PSA was measured in nanograms per milliliter $(\mathrm{ng} / \mathrm{mL})$. The results of PSA are supplied by the laboratory in decimal fractions. The acinous area and the area of acinous epithelium in squared micrometers $\left(\mu \mathrm{m}^{2}\right)$ and the AgNORS in number of argyrophilic clusters found in acinous nuclei for $\mu \mathrm{m}^{2}$.

Five hundred acinous nuclei were assessed for the counting of argyrophilic clusters in each assessed slide, and the amount of clusters in every slide represented the AgNORs expression for each animal (Figure 6). 


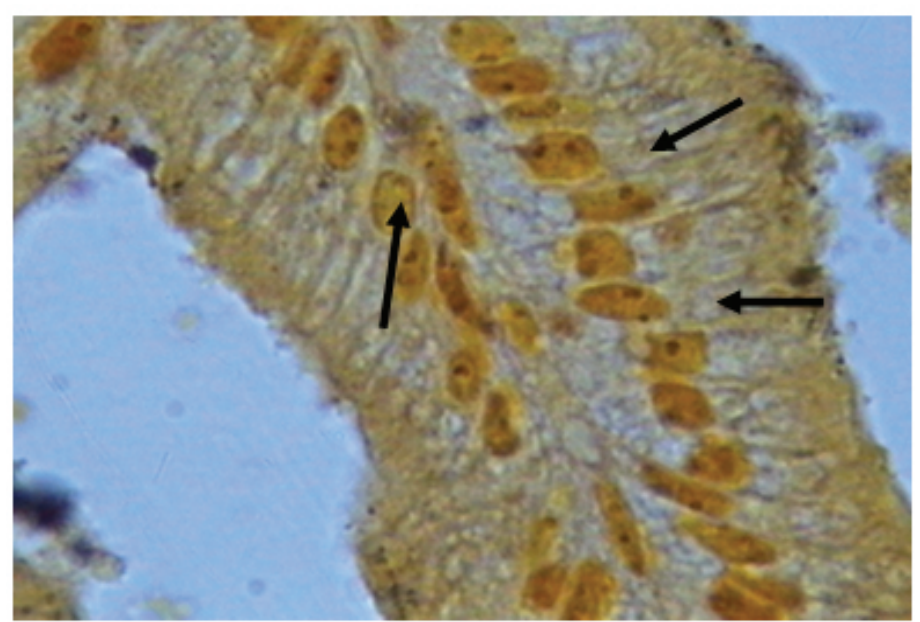

FIGURE 6 - Digital photomicrography of the acinous epithelium from prostate of an adult $\mathrm{h} M a$. The arrows shows the argyrophills clusters (40x objective lenses)

Following, the data were statistically analyzed.

\section{Statistics}

This was a random and double-masked study. The data were analyzed with the softwares "Stata 9.2" (licensed for Medicine School of Barbacena) and "GraphPad Prism" version 3.0 (licensed for ICB-UFMG).
The frequency distribution, means, standard deviations (SD), and proportions relative to the study variables (serum PSA, acinous area, acinous epithelium mean area, AgNORs, apoptosis and cellularity) were calculated. The groups $\mathrm{RxC}$ contingency tables were compared for frequency, and ANOVA table was used for means comparison. The Fishers exact test (for two sides of the distribution) and Study $t$ test were used for proportions and means measurement, respectively. After Bartlett test, when mean variances were not similar $(p<0.05)$ the Kruskal-Wallis $(\mathrm{H})^{12}$ or Mann-Whitney (with ties), were then used for evaluation of differences between groups.

The logistic regression models were used for adjustment of the treatment with finasteride and the serum-PSA levels with the effect of animals' age and weight noticed in the analyses. The original values of age and weight, and the decimal $\operatorname{root}\left(\mathrm{V}^{10}\right)$ of the original PSA values were used in the logistic analyzes, aiming to 'normalize' this variable distribution. was of 0.05

The statistical level of significance adopted in the analyses

\section{Results}

The Table 1 shows the frequency distribution of variables age, weight and PSA.

The mean age (SD) for the animals in the experimental group and for the control group was $17.7 \pm 0.67$ months and $15.2 \pm 1.13$ months, respectively. The $t$ value for the comparison of mean age between groups was 5.98 ( $p=0.001)$. The mean weight (SD) for the animals in the experimental group and for the control group was $145 \pm 15.27 \mathrm{~g}$ and $129 \pm 18.82 \mathrm{~g}$, respectively. The comparison of mean weight between groups rendered $t=2.08$ and $p=0.0514$.

TABLE 1 - Frequency distribution of variables age, weight and PSA for experimental versus control group

\begin{tabular}{c|c|c|c}
\hline Caracteristics observed & $\begin{array}{c}\text { Experimental Group } \\
(\%)\end{array}$ & $\begin{array}{c}\text { Control Group } \\
(\%)\end{array}$ & $p$ \\
\hline Age (months) & $1-10$ & $10-100$ & $<0.001$ \\
$12-16$ & $9-90$ & $0-0$ & \\
$17-18$ & $3-30$ & $9-90$ & 0.020 \\
$100-140$ & $7-70$ & $1-10$ & \\
$141-180$ & & & \\
\hline Weight (grams) & $10-100$ & $1-30$ & 0.003 \\
$0.0-0.01$ & $0-0$ & $7-70$ & \\
\hline $0.02-2.10$ & & & \\
\hline
\end{tabular}


The mean PSA for the experimental group was $0.003 \pm 0.0048$ $\mathrm{ng} / \mathrm{mL}$, and for the control group was $0.633 \pm 0.763 \mathrm{ng} / \mathrm{mL}$. The experimental group versus control groups means comparison showed $t=2.61$ and $p=0.0176$, with Bartlett's $p<0.05$. The MannWhitney or H test for samples was $7.982(p=0.0047)$.

The hMa ages were removed from the logistic regression analyzes because they did not showed sufficient variations in the $<16$ months old subgroup in the experimental group, and $>16$ months old subgroup in the control group. The dependency relation between age and weight (weight over age regression was $b=6.43 \pm 4.92$; the correlation coefficient between the variables was 0.5438 ) corresponded to the other factor that has determined the exclusion of age in the selected model used to describe the correlation between finasteride use and serum-PSA levels.

The logistic regression model used in the simultaneous effect test for the study variables on the probability of the animal be or not using finasteride, considered only the fact of animals beeing in the control or experiment groups, the animals weight and the serum- $P S A$ concentration. The logistic regression coefficients found in the analyses for PSA was -3.100 [(-5.931)-(-0.271); $p=0.032]$ and for weight was $0.038(-0.030-0.106)(p=0.268)$. The odds ratio was $0.045(0.003-0.763)$ for PSA and $1.04(0.971-1.112)$ for weight. The result of the chi-square global model was $9.72(p=0.0078)$, and chi-square for the Hosmer-Lemeshow test was $3.37(p=0.4986)$.

The acinous area and the acinous epithelium area, AgNORs expression and number of marked cells in the TUNEL reaction, indicatives of apoptosis, as well as the acinous cellularity are shows in Figures 7 to 11 .

Figure 7 shows a significant reduction of acinous area for the animals that received finasteride. The comparison between both groups showed $t=2.653 ; p=0.0122$. The values showed were: mean of $398.600 \pm 55.320 \mu \mathrm{m}^{2}$ for the control group and mean of $238.000 \pm 24.600 \mu \mathrm{m}^{2}$ for the experimental group.

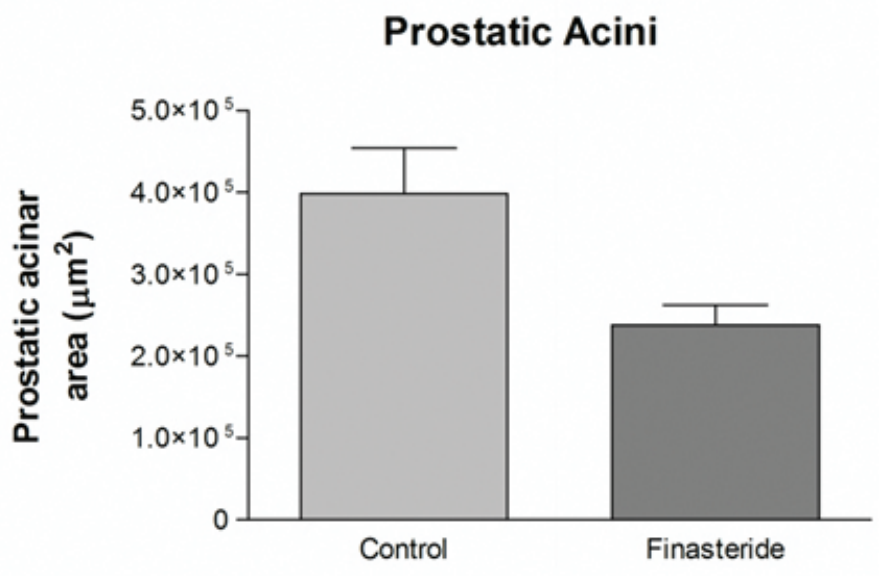

FIGURE 7 - Relation control-animals versus experimental group regarding to acinous area

Figure 8 shows the mean acinous epithelium area for the animals in both control and experimental groups. It can also be observed a significant reduction of the acinar epithelium in the animals that were treated with finasteride. The comparison between the two groups reveled $t=2.162 ; p=0.0361$. The values showed were: mean of $160.400 \pm 18.430 \mu \mathrm{m}^{2}$ for the control group and mean of $111.900 \pm 12.820 \mu \mathrm{m}^{2}$ for the experimental group.

\section{Prostatic Acinar Epithelia}

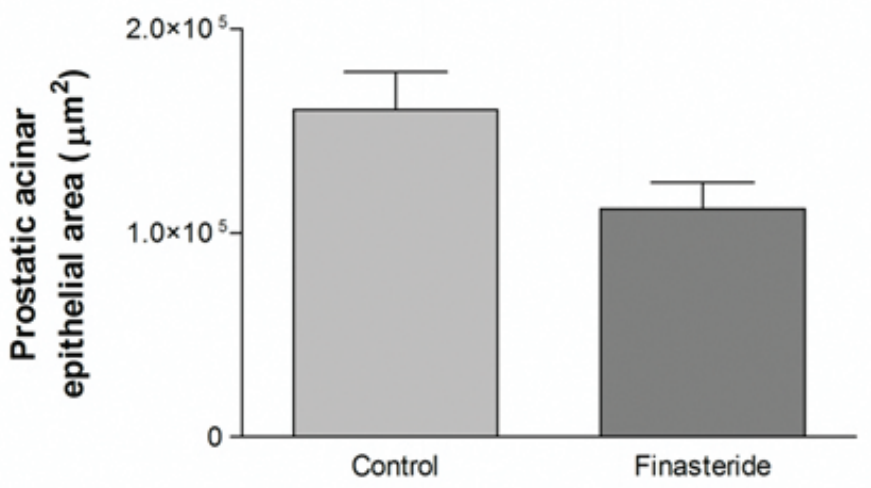

FIGURE 8 - Relation control-animals versus experimental group regarding to epithelium area

Figure 9 shows the expression of AgNORs. There was a statistically significant difference between the two groups of animals. The control group showed a mean of $3.68 \pm 1.07$ clusters of $\operatorname{argyrophils} / \mu \mathrm{m}^{2}$ and $p=<0.0001$. The experimental group showed a mean of $2.846 \pm 0.877$ clusters of $\operatorname{argyrophils} / \mu \mathrm{m}^{2}$ and $p=<0.0001$.

\section{AgNORs Expression}

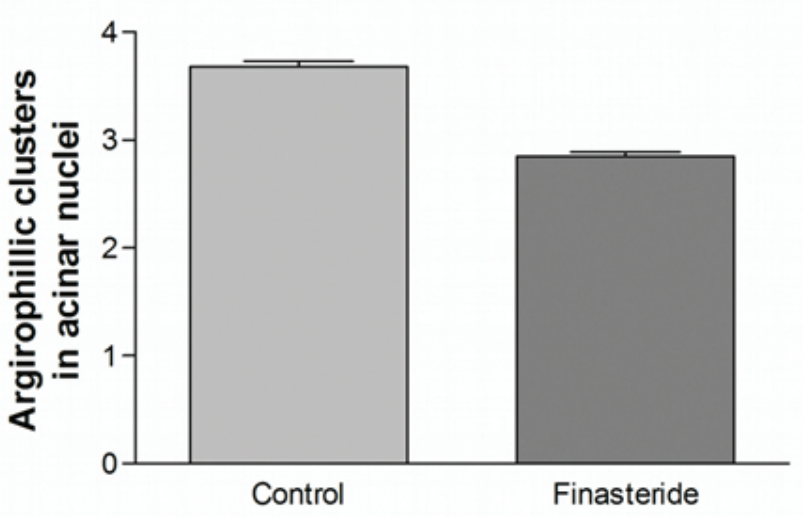

FIGURE 9 - Relation control-animals versus experimental group regarding to AgNORs

Figure 10 shows the result of apoptosis between the control and experimental groups. The control group showed mean of $14.76 \pm 2.137$ and the experimental group showed mean of 53.62 \pm 1.389 and $p=0.0408$. The experimental group showed a more evident apoptosis. 


\section{Apoptosis}

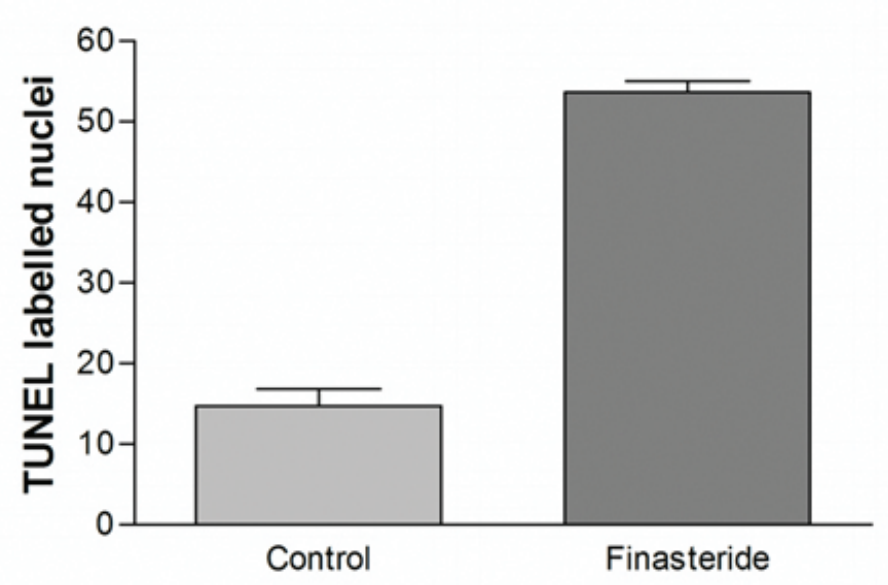

FIGURE 10 - Relation control-animals versus experimental group regarding to apoptosis

There was no significant difference in cellularity between the groups. The mean for the control group was $75 \pm 5$ cells $/ \mu \mathrm{m}^{2}$, and for the experimental group was $65.07 \pm 13.24$ cells $/ \mu \mathrm{m}^{2}$. The mean difference between the two groups was $p=0.5105$. This relation is showed in Figure 11.

\section{Acinar Cellularity}

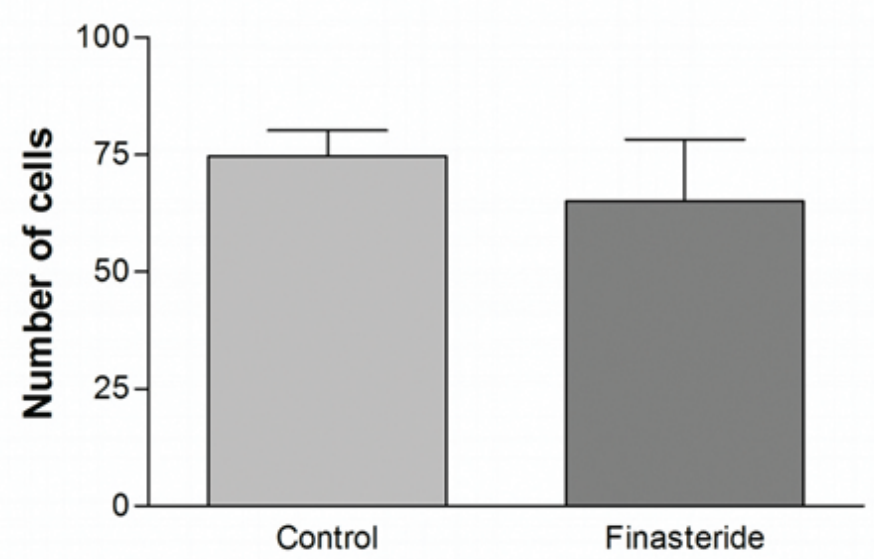

FIGURE 11 - Relation control-animals versus experimental group regarding to cellularity

\section{Discussion}

The present study aims to discuss the effect of finasteride on serum PSA and on prostate of $\mathrm{h} M a$. Finasteride was administered subcutaneously to the experimental animals, what makes the drug absorption reliable and turns the data shown here trustful.

The cellular mechanism of action of finasteride on prostate is not yet well understood. It has been shown that finasteride act in the androgenic receptor of alpha-5-reductase type 2 in prostate of men $^{13}$. The present study suggests that the androgenic receptors in prostate of hamster are also of type 2 and that serum PSA is under androgenic action.
The results showed that animals treated with finasteride have statistically significant lower serum-PSA levels compared to control group. However, results were also significantly different in age and weight comparison. The animals in the control group were younger and lighter than those treated with finasteride, although it was not possible to show differences among weights when using the Student $t$ test for mean weight comparison.

However, the comparison grouped classes of age and weight and the comparison of these variables distribution into the two groups, analyzed with chi-squared and Mann-Whitney tests were capable of showing the differences reported.

The investigation performed in order to determine the possible interference of weight and age in the serum-PSA differences has indicated that the statistical correlations among finasteride, $P S A$ and weight were significant (high global chi-square and $p<0.05$ ), when simultaneous effects of a variable over another were considered in the analyses.

The results also showed that the effect of finasteride on serum-PSA is not weight dependant, since the relation between first two showed $p<0.05$ (weight was included in the analyses). It was also found that the animals with higher serum-PSA levels were more likely to not use finasteride, and that the use of the drug was a protection factor against increasing in serum-PSA level (odds ratio $<1)$.

The modest value in the Hosmer-Lemeshow test may be the only fact that shows some lack of model accuracy to adequately describe the correlations between finasteride and PSA, considering animals' weight. This result shows a moderate model adjustment to the available data. However, this value does not nullify the conclusions, and caution is recommended when using the information provided by this study.

The animals that did not receive finasteride showed higher PSA levels than the experimental group ( $p=0.0047)$. Guess et al. ${ }^{14}$ showed that the administration of finasteride to men for treatment of BPH promoted the lowering of serum PSA concentrations, and that the level of PSA after six to twelve months from treatment beginning, fell to $50 \%$ of the initial concentration, what was also found in this study. We observed a significant reduction in PSA concentrations of the animals that received finasteride when compared to the control group.

Finasteride was administered to the animals in this study three times per week, with a significant impact on prostate, proposing a longer period of use in men, thus reducing the costs of acquisition, the adverse effects, while keeping the therapeutic effects. Finasteride is used for treatment of BPH in men in a $5 \mathrm{mg}$ dose daily ${ }^{15}$

The prostate stroma of $\mathrm{hMa}$ is composed of loose connective tissue where the prostatic acinous are attached ${ }^{10}$. In men, the prostate stroma is rich in fibermuscular tissue. It has been shown a reduction in prostatic volume of men that used finasteride. There is still a lack of histological data that confirm these clinical and epidemiological evidences. We were able to observe in this study an acinous area reduction $(p=0.0122)$ and a prostate epithelium reduction $(p=0.0361)$ in the animals treated with 
finasteride. Such observation could not be confirmed for the stroma due to the structural differences between the prostates of man and hamster.

Androgen receptors (AR) and alpha-5-reductase are found in gland epithelium and in prostate stroma, what causes these two sites to be sensitive to the action of dihydrotestosterone (DHT) ${ }^{15}$. The urinary flow obstruction in man has a mechanic component, represented by the structural augment of the prostate, and a dynamic component, represented by the stroma loose muscle tonus and the prostate capsule ${ }^{2}$. This loose muscle tonus is mediated by the alphaadrenergic activity ${ }^{16}$. The prostate stroma is rich in alpha-adrenergic receptors, which when activated cause the prostatic urethra to constrict under loose muscle stimulus ${ }^{16}$. The morphometric findings showed a reduction in the diameter of acinous, as well as the acinous area of prostate for the animals that received finasteride, causing a prostate shrinking that justifies the clinical observation, which is in fact the clinical benefit of using alpha-blockers associated to finasteride for the BPH treatment ${ }^{17}$. Is of wide knowledge that the hyperplasic gland tissue is the "static or mechanic" obstructive process forerunner, while the dynamic effect of the prostate obstruction would be a result of muscle hypertonicity at stromal, prostate capsule and bladder neck levels ${ }^{2}$.

Random and double-masked study population investigations have shown the benefits of finasteride action on the proliferative processes in prostate of men ${ }^{18}$. Others have shown that AgNORs are primarily associated with cell proliferation ${ }^{19}$. In our study, we could verify that the experimental animals showed a significant reduction of AgNORs $(p=0.0001)$ and an increased apoptosis, suggesting that the use of finasteride could promote the blocking of cell proliferation in prostate of men in like it happened to the animals that were given the drug. Apoptotic mechanisms dysfunctions are also implicated in the development and progression of proliferative processes of prostate ${ }^{20}$. These arguments suggests that finasteride can protect the prostate against proliferative hyperplasic and neoplasic events.

There was not a statistic significant difference between the groups regarding to the number of cells, $p=0.510$. This finding suggests that this time of 90 days of treatment was not long enough to reduce the number of cells in the acinous of these animals, although, there was a reduction in the lumen of this acinous, the acinous epithelium, the AgNORs, and a stimulus for the apoptosis. Possibly with the medication continuation it would be seen a difference in the cellularity between the groups on study. Other studies have shown that is necessary a six month therapy with finasteride to elicit a tissue response ${ }^{21}$, what justifies the observations in this experiment.

Other studies ${ }^{22}$ have shown that small amounts of isoenzyme-1 are capable of maintaining prostatic volume. Since DHT does not act on prostate isoenzyme-1, such fact can also justify the results found in cellularity in this study.

There were difficulties in counting the cells due to the heterogeneity of the histological sections analyzed. The histological sections were carried out in distinct planes, since the prostate of the animals were fixed en bloc, not always in the same pattern. This was another uncontrolled variable that might have influenced in the reduction of the power of the test and made impossible the differentiation among the values obtained between the groups.

Important adverse effects of finasteride have been shown by other studies in a dose of $5 \mathrm{mg}$ day $^{23,24}$. The most important is the libido reduction, followed by reduction in the ejaculated volume and erectile disturbances (ED) ${ }^{24}$. However, other studies have demonstrated similar adverse effects in patients who used finasteride and those who used placebo ${ }^{24}$. Women who had contact with finasteride have given birth to babies with malformations ${ }^{25}$. Finasteride reduces the plasmatic levels of PSA, what could impair the detection of an eventual prostate neoplasia ${ }^{14}$. Vidigal et al. ${ }^{26}$ observed significant tubular atrophy and reduction of spermatogenesis in $\mathrm{h} M a$ that were administered finasteride.

More rigorous studies must be carried out to obtain a safe dose of finasteride regarding to the benefic and adverse effects of this medication, as well as the ideal age to initiate the treatment in men. The review of our literature ${ }^{27,28}$ and the results shown in here demonstrate that finasteride is a promissory drug for the prevention and treatment of the proliferative processes of prostate, nevertheless, we cannot yet consider such a drug as a solution for the control of BPH because there are doubts, such as its action on the cellularity.

\section{Conclusions}

The use of finasteride reduced serum PSA, luminal areas, acinous epithelium areas and the expression of AgNORs. It also promoted apoptosis of acinous in prostate of animals in the experimental group. There was no statistical significant difference in acinous cellularity in the studied groups of animals.

\section{References}

1. Berry SJ, Coffley DS, Walsh PC, Erwing LL. The development of human prostatic hyperplasia with age. J Urol. 1984;132:474-9.

2. Srougi M. Tratamento médico da hiperplasia de próstata. Rev Bras Med. 1995;ed. especial;52:28.

3. Rasmusson GH, Reynolds GF, Steinberg NG, Walton E, Patel GF, Liang T, Cascieri M A, Cheung AH, Brooks JR, Berman C. Azasteroids: structure-activity relationships for inhibition of 5-alfa reductase and of androgen receptor binding. J Med Chem. 1986;29:2298-315.

4. Barry MJ, Fowler FJ, O'Leary MP, Bruskewitz RC, Holtgrewe HL, Mebust WK. Correlation of the American Urological Association Symptom Index with self-administered versions of the Madsen-Iversen, Boyarsky and Maine Medical Assessment Program Symptom Indexes. J Urol. 1992;148:1558-63.

5. Tammela T, Konttury M. Urodynamic effects of finasteride in the treatment of bladder outlet obstruction due to prostatic hyperplasia. J Urol. 1993;149:342-4.

6. Ball AJ, Feneley RC, Abrams PH. The natural hystory of untreated "prostatism". Br J Urol. 1981;53(6):613-6.

7. Silver RI, McConnell JD. Androgen suppression therapy for benign prostatic hyperplasia. Curr Opin Urol. 1994;4:22-8.

8. Li NC, Wu SL, Jin J, Qiu SP, Kong CZ, Song YS, Ye ZQ, Sun G, Sun YH, Sun YC, Wang XF, Na YQ. Comparison of different drugs on the treatment of benign prostate hyperplasia. Chinese J Surg. 2007;45:947- 
50 .

9. McConnell JD, Bruskewitz R, Walsh P, Andriole G, Lieber M, Holtgrewe HL, Albertsen P, Roehrborn CG, Nickel JC, Wang DZ, Taylor AM, Waldstreicher $\mathrm{J}$. The effect of finasteride on the risk of acute urinary retention and the need for surgical treatment among men with benign prostatic hyperplasia. Finasteride long-term efficacy and safety study group. N Engl J Med. 1998;338(9):557-63.

10. Toma JG, Buzell GR. Fine structure of the ventral and dorsal lobes of the prostate in the young adult Syrian Hamster, Mesocricetus auratus. Am J Anat. 1988;181(2):132-40.

11. Vidigal DJA, Silva LA, Fonseca LMA, Resende DF. Técnica para obtenção do aparelho geniturinário e dosagem do PSA (Prostate Specific Antigen) no Hamster Sírio, Mesocricetus auratus. Acta Cir Bras. 2004;19(6):603-8.

12. Zar JH. Biostatistical analysis. Prentice-Hall, Inc-Englewood Cliffs. N.J.; 1984. p.141 (Mann Whitney), 176 (Kruskal-Wallis).

13. Steers WD. 5alpha-reductase activity in the prostate. Urology. 2001;58 (Suppl 1):17-24.

14. Guess HA, Gormley GJ, Stoner E, Oesterling JE. The effect of finasteride on prostate specific antigen: review of available data. J Urol. 1996;155:3-9.

15. Coffey DS, Walsh PC. Clinical and experimental studies of benign prostatic hyperplasia. Urol Clin North Am. 1990;17:461-75.

16. Furuya S, Kumanoto Y, Yokoyama E, Tsukamoto T, Izumi T, Abiko Y. Alpha-adrenergic activity and urethral pressure in prostatic zone in benign prostatic hypertrophy. J Urol. 1982;128:836-9.

17. McConnell JD, Roehrborn CG, Bautista OM, Andriole GL Jr, Dixon CM, Kusek JW, Lepor H, McVary KT, Nyberg LM Jr, Clarke HS, Crawford ED, Diokno A, Foley JP, Foster HE, Jacobs SC, Kaplan SA, Kreder KJ, Lieber MM, Lucia MS, Miller GJ, Menon M, Milam DF, Ramsdell JW, Schenkman NS, Slawin KM, Smith JA; Medical Therapy of Prostatic Symptoms (MTOPS) Research Group. The long-term effect of doxazosin, finasteride, and combination therapy on the clinical progression of benign prostatic hyperplasia. N Engl J Med. 2003; 349(25):2387-98.
18. Kramer BS, Hagerty KL, Justman S, Somerfiled MR, Albertsen PC, Blot WJ, Carter HB, Costantino JP, Epstein JI, Godley PA, harris RP, Wittes J, Zon R, Schellhammer P. Use of 5-alpha-reductase inhibitors for prostate cancer chemoprevention: American Society of Clinical Oncology/ American Urological Association 2008 clinical practice guideline. J Urol. 2009;181(4):1530-1.

19. Derenzini M, Trerè D. AgNOrs proteins as a parameter of the rapidity of cell proliferation. Zentralbl Pathol. 1994;140(1):7-10.

20. Bruckheimer EM, Kyprianou N. Apoptosis in prostate carcinogenesis. A growth regulator and therapeutic target. Cell Tissue Res. 2000;301(1):153-62.

21. Kirby RS, Vale J, Bryan J, Holmes K, Webb JAW. Long-term urodynamic effects of finasteride in benign prostatic hyperplasia: a pilot study. Eur Urol. 1993;24:20-6.

22. Steers WD. 5alpha-reductase activity in the prostate. Urology. 2001;58 (suppl 1):17-24.

23. Gormley GJ, Stoner E, Bruskewitz RC. The effect of finasteride in men with benign prostatic hyperplasia. N Engl J Med. 1992;92:903-10. 24. Finasteride Study Group. Finasteride (MK-906) in the treatment of benign prostatic hyperplasia. Prostate. 1993;22:291-9.

25. Lechuga SAM, Hernández SR, González CI, Gracia BR. Newborn with bladder extrophy associated with finasterida exposure. An Pediatr. 2004;61(5):451-3.

26. Vidigal DJA, Silva AL, Fonseca LMA, Vasconcelos AC, Resende DF, Vidigal FEC. The Effect of finasteride on spermatogenesis of adult syrian hamster Mesocricetus auratus. Acta Cir Bras. 2008;23(3):282-6.

27. Reed AB, Parekh DJ. The utility of 5-alpha reductase inhibitors in the prevention and diagnosis of prostate cancer. Curr Opin Urol. 2009);19(3):238-42.

28. Thompson IM, Goodman PJ, Tangen CM, Lucia MS, Miller GJ, Ford LG, Lieber MM, Cespedes RD, Atkins JN, Lippman SM, Caslin SM, Ryan A, Szczepanek CM, Crowley JJ, Coitman CA JR. The influence of finasteride on the development of prostate cancer. N Engl J Med. 2003;349(3):215-24.

\section{Correspondence:}

Conflict of interest: none Financial source: none

\section{Dimas José Araújo Vidigal}

Rua Augusto Justi, 74

36210-613 Barbacena - MG Brazil

Phone/Fax: (55 32)3331-0124

dimas@barbacena.com.br

Received: August 18, 2009

Review: October 21, 2009

Accepted: November 19, 2009

\section{How to cite this article}

Vidigal DJA, Lázaro da Silva A, Vasconcelos AC, Fazito DR, Verçosa BLA, Santana NG, Vidigal FEC. Effect of finasteride on serum prostate-specific antigen (PSA) and on prostate of hamster Mesocricetus auratus (hMa). Acta Cir Bras. [serial on the Internet] 2010 JanFeb;25(1). Available from URL: http://www.scielo.br/acb 